\title{
太行山“岗底模式” 科技扶贫机制的创新*
}

\author{
张月辰 $^{1,2 a}$, 赵国杰 ${ }^{1}$, 陶佩君 ${ }^{2 b}$ \\ (1. 天津大学管理学院，天津 $300072 ； 2$. 河北农业大学 a. 科技管理处；b. 农学院，河北保定 071001)
}

摘 要 : 河北省内丘县岗底村将科技扶贫项目与当地自然、人力资源有机结合, 将外部支持和内源发 展有效衔接。走出了一条自我脱贫，自主发展的参与式扶贫之路，创造了扶贫开发和保护生态相结合的 岗 底模式”。本文从政策观念、扶贫理念、治山理论、技术方法、经营管理五方面，透视了太行山“岗底模 式” 科技扶贫机制的创新。对于促进贫困地区可持续发展，建立和完善中国特色参与式扶贫机制具有重要 借鉴意义, 并为新农村建设提供了重要参考。

关键词：岗底模式; 参与式; 科技扶贫 ; 可持续发展

面对贫困地区资源紧缺、生态环境脆弱，发展相对滞后的困境，如何让贫困群众作为发展主体全面参 与扶贫开发，促进区域资源、人口和环境的良性循环，实现贫困地区经济、社会的协调可持续发展，是当 前建设社会主义新农村迫切需要解决的问题。河北省内丘县岗底村将科技扶贫项目与当地自然、人力资源 有机结合, 将外部支持和内源发展有效衔接。走出了一条自我脱贫, 自主发展的参与式扶贫之路，创造了 扶贫开发和保护生态相结合的成功模式。本文将从太行山“岗底模式” 透视科技扶贫机制创新的问题。

\section{一、太行山“岗底模式”}

\section{(一) 背景分析}

河北省内丘县岗底村地处太行山深处，历史上素有“ 九龙岗下穷山庄，山秃地贫收入少，十有九年闹 饥荒” 的穷名。改革开放前除了 7800 亩荒山野岭，200 亩耕地外，村里集体积累分文全无。全村 169 户， 570 口人, 年人均收入不足 80 元。岗底村自然环境恶劣, 大山阻挡了大部分村民走向外界寻求发展之路, 封闭的意识、闭塞的交通和落后的信息，把村民的眼光局限在人均 3 分田上。

1984 年家庭联产承包责任制后，岗底村把山场全部放到各户。可 3 年过去了，村民除了靠采一些矿石 赚点辛苦钱外，就只有守着 7800 亩荒山苦謷岁月。一家一户的分散经营，导致治山投不起资，水利设施 建不起，技术人员请不起，许多农户索性把分给自己的山场闲置撂荒。山场无人看护，牲畜放养无序，滥 采滥伐严重。这些突出的问题限制了山场合理开发，严重破坏了当地的生态平衡。

1988 年在政府宏观指导和扶贫项目的资助下 , 在河北农大专家教授的技术指导下，特别是广大村民的 主动参与下，岗底人用自己的聪明智慧创造了“治山一绿山一富民”的成功模式，被三次来村考察的德国 经济学家鲁道夫称为“岗底模式”。这种发展模式蕴涵着扶贫理念和方法的创新，具体如下。

(二) 科技扶贫机制的创新

\footnotetext{
* 本研究受国家科技部科普专项经费课题资助 (KP-2005-05)。

【作者简介】

张月辰 (1964-), 男, 研究员, 天津大学管理学院在读博士, 现在河北农业大学科技管理处工作; 研究方向：农业科技 项目管理、农村区域发展。

赵国杰 $(1950$ - )，男，天津大学管理学院教授，博士生导师；研究方向：技术经济及管理。

陶佩君 (1964-)，女，河北农业大学农学院教授 ; 研究方向：农村发展与农业推广。
} 
1. 政策观念的创新。岗底人脱贫致富的关键是以人为本，解放思想，观念创新一一宜统则统，宜分则 分，统分结合。但是，“收”是否与当时中央要求的“两山下放”政策相抵触? 村党支部书记杨双牛经过 反复学习党的现行土地承包经营政策，从中悟出了深奥的道理 : 在实际工作中必须实事求是创造性地落实 好家庭联产承包责任制。要想治好山, 致富一方百姓, 就必须首先解决一家一户自身想解决而解决不了的 问题。党中央的政策并不只是分，更不是分得越小越好，只要是对治理荒山有利，对村民脱贫致富有效， 不管是分是统都是正确的。

2. 扶贫理念的创新。杨双牛深深感到: 只靠救济解决不了贫困的根本问题，只有将广大村民组织起来， 自觉投身于治山治水的开发建设中，脱贫致富才会有不竭的动力。“统一收回山场，放山不放羊”，“收荒 山是为了放绿山”。杨双牛把这些想法通过村领导班子会、党员骨干会和村民代表大会向全体村民反复宣 讲。当时就有 130 户村民带头签字画押，治山很快成了全村上下一致的强烈意愿。在河北农大专家教授的 科学规划下, 党支部、村委会带领全体村民, 按照“统一设计规划、统一组织施工, 统一组织服务、统一 质量标准、统一检查验收，分户承包经营”的“五统一分” 治山路子 ; 及“分户专业承包、分散经营管理、 分类技术指导、分清权力责任、分级独立核算、统一品牌销售” 的“五分一统” 管山办法。开始了长达十 几年科学艰难的治山治水历程。

3. 治山理论的创新。河北农业大学经过二十多年太行山科技扶贫开发的摸索，总结出了一套治山的 两 聚理论”。即聚集土壤、聚集水分(径流)。太行山区土层薄，可采取把 $3 \sim 8 \mathrm{~m}$ 宽的土层聚集到 $1 \sim 2 \mathrm{~m}$ 宽的 沟槽里, 相应的径流也聚集到这么宽的沟里集中使用, 使荒山长出植被来, 为荒山的植被生长创造了较好 的条件。根据这个理论, 按照隔坡沟状梯田方式, 岗底村对上千亩山场进行了整治, 在 $5 \sim 6 \mathrm{~m}$ 宽的山坡内 埋炸药进行爆破, 开一个 $1 \mathrm{~m}$ 深、1.5 2m 宽的水平沟槽, 把坡面上的好土集中到沟槽里, 形成一个外面 高里面低的小缓坡梯田，梯田与梯田中间有 3 8m 宽的坡面 (未爆破)保持稳定性，降雨时在坡面形成的 径流可以流到下一个梯田里，既保住了土，又保存了水。一改过去俗称“花盆效应”的“鱼鳞坑”、“石坎 梯田” 的治理方式。1996 年 8 月 3 5 日, 太行山南部普降 500 mm 以上的大雨, 造成严重的洪涝灾害, 唯有岗底村从山上流下来的竟是涓涓清流!“两聚理论”治山效果可见一斑。

4. 技术方法的创新。荒山治了，选准岗底村农业产业发展目标已迫在眉睫。1996 年岗底人用诚心请 来了河北农大的果树专家李保国教授, 专家仔细分析了岗底村, 海拔 $500 \sim 1200 \mathrm{~m}$, 昼夜温差 $\geq 15^{\circ} \mathrm{C}$; 土 壤为片麻岩的中性偏酸性、富含 $\mathrm{p} 、 \mathrm{k} 、 \mathrm{Ca} 、 \mathrm{Mg}$ 元素; 水质好; 日照充足等自然条件。认定岗底的自然条 件有利于果品糖分积累且适口性好，是理想的无公害绿色果品基地；怎样让果品优质优价？

只有增加果品的科技含量，让科技进村，技术入户。于是，岗底村成立了果树生产管理中心，严格按 照无公害绿色果品技术标准生产。并从果园的土一果树一病一虫一草等生态系统出发, 创造不利于病虫生 存、有利于各类天敌繁衍的环境条件，保持了果园生态系统的平衡。如，病虫害防治以物理、生物、无公 害农药防治为主; 施肥以农家肥和硼、锌、铁肥为主, 无公害金秋液肥为辅, 并根据土壤理化性质检测配 方施肥 ; 引进了苹果套袋、晒字、覆反光膜等多项新技术 ;

经过果农们“ 120 道工序” 的精心管理, 加上得天独厚的光、水, 土自然资源优势, 使富岗苹果具备 了身价陡增的内在品质。经中国农业大学食品学院检测，岗底苹果果实硬度 18.9 磅/cm2, 含水量 $89.3 \%$, 果肉脆、多汁、质地细、纤维少; 果肉含原糖 $8.7 \%$, 蔗糖 $15.1 \%$, 可溶形固体物含量 $16.1 \%$; 果肉滴定酸 0.295\%量较高，果汁 PH 值 3.3 ，有典型的芳香味，以上指标均高于全国代表值。内含有 18 种氨基酸，15 项均高于全国代表值，品质胜过日本长野富士苹果。2001 年 1 月获中国绿色食品证书。

5. 经营管理的创新。富岗苹果依靠科技创新实现了高品质, 而进一步实现高价位就必须通过产业化公 司运作，打造“富岗” 品牌。诚然，名牌背后是文化，是经营管理的创新。1997 年 1 月岗底苹果正式注册 了全省第一个“富岗”牌苹果商标, 并成立了集生产、服务、销售为一体的龙头企业一一富岗集团。在考 
察了国内外苹果市场之后，大胆将富岗苹果市场定位在高消费群体上，并制定了“515” 销售战略：一级 果 5 元/个，特级果 10 元/个，极品果 50 元/个。如今，吃上带有红底绿字“福”、“禄”、“寿”、“喜”的富 岗苹果, 感到价值超然于物外。一吃名儿, 二吃派儿, 三吃味儿, 四吃鲜儿, 五吃营养, 六吃绿色。这六 吃当中，味、鲜、营养吃的是苹果，而名、派、绿吃的则是品位。凭借“富岗” 名牌战略，加上成功的市 场运作，富岗集团把“蛋糕”越做越大。

二、“岗底模式”取得的成效

(一)“岗底模式”取得了扶贫开发和保护生态双赢的效果

岗底人用自己创造的“岗底模式”，按高标准治理开发了“三沟两峪一面坡”，治理面积达 2700 亩， 动土石 210 万 $\mathrm{m}^{3}$ ，累计投工 40 万个，栽果树 15 万株，山场绿化面积达 $76.6 \%$ ，生态环境得到了显著改善。 现如今岗底已是：山顶水土保持林戴帽 (主要是洋槐树), 经济林揽腰(主要种植较耐旱的板栗、柿子), 水 果抱山脚 (主要栽植优质红富士苹果) ; 在目前大路果品供过于求, 价格低落的大环境下, 富岗苹果却能以 50 元/个的价位一枝独秀。且 1999 年“富岗” 牌一级苹果获得了世界园艺博览会铜奖。以富岗集团公司为 龙头的 6 家集体企业, 村集体固定资产达到 5600 万元, 人均纯收入达到 3000 多元。其中仅苹果一项亩收 益就达 8000 元 10000 元，人均果品收入 1800 元。

“岗底模式”带来的区域生态环境改善是有目共睹的，显示出的经济绩效更是艮庸置疑的。正像德国 经济学家鲁道夫所言：这种治山模式兼顾生态效益、经济效益和社会效益，适合于发展中国家推广应用。

(二)“岗底模式”带来了村民科技接受心理和行为的转变

通过科技扶贫项目的实施及河北农大专家教授的技术培训，示范指导，加上“两聚理论” 的治山模 式及先进成熟的无公害绿色果品生产技术, 能满足农民需要, 解决农民迫切需要解决的问题, 为岗底发展 创造了良好的外部环境 ; 特别是在核心人物杨双牛和村领导班子带动下，因地制宜地开展“五统一分” 治 山、“五分一统” 管山，使村民群体的科技意识和行为观念开始产生变化。因为农民受见识、经验、知识 等自身条件所限，很容易产生从众心理，往往追随心目中的领袖人物行事，领袖人物的思想和行为带动并 影响着农民群体；随后，在富岗苹果“515”市场价位等外在利益诱导下，岗底村民迫切需要脱贫致富的 内在需求愿望和强烈的潜能被全面激活，导致农民科技接受心理和行为的转变，采用新技术的积极性空前 高涨, 由被动接受到主动索取新技术并参与安排生产和销售；另外，以市场为导向，以利益为诱因，以市 场和生产的变化为依据，针对生产和销售环节，不断调整技术内容，实现产销协调发展的产业化公司运作， 实现了农村要素资源的最优配置, 最终实现了农民增收、农业与农村的可持续发展, 最终带来了农民科学 知识、技能、态度、行为的自愿变革。

\section{三、“岗底模式”的重要借鉴意义}

(一)“岗底模式”对于促进贫困地区可持续发展的借鉴意义

贫困最早是由英国社会学家郎特里提出的，他把绝对贫困线称之为“初级贫困线” (Primary Poverty Line)。世界银行在其出版的 《1990 年世界发展报告》中把贫困定义为“缺少达到最低生活水准的能力” 并提出了相应的衡量标准。贫困问题的根源在于没有很好地认识和处理好资源、社会与人的发展之间的关 系。由贫困与经济发展陷阱图 1 可以看出, 生态系统、经济系统、社会系统彼此交织所构成的恶性循环, 其中资源的不合理开发利用和生态环境的恶化是造成贫困的重要原因之一。

“岗底模式”作为扶贫开发和保护生态相结合成功范式，兼顾生态效益、经济效益和社会效益，适合 于发展中国家推广应用，对于促进发展中国家区域可持续发展具有重要借鉴意义。 


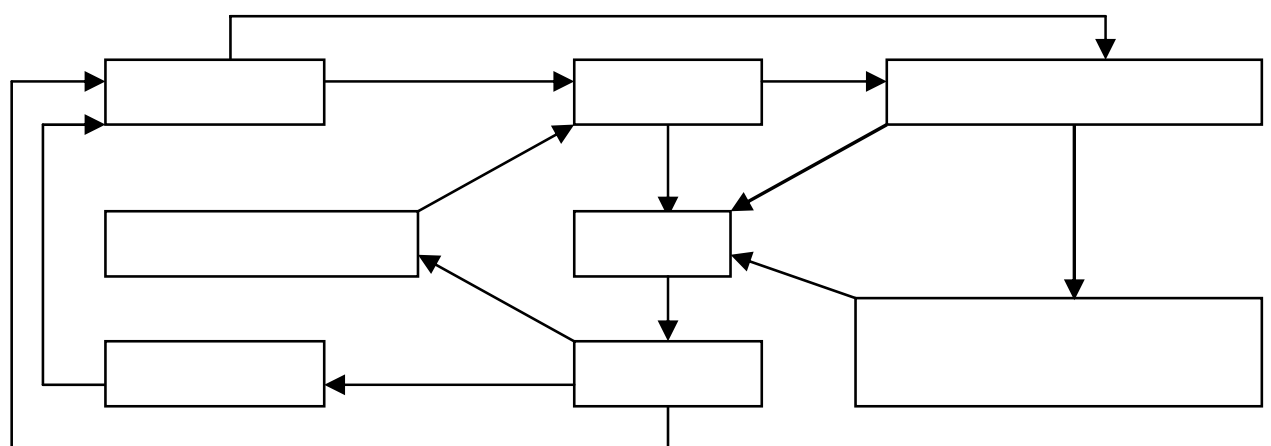

图 1 贫困与经济发展陷阱图

(二)“岗底模式”对于建立和完善中国特色参与式扶贫机制的借鉴意义

通过对“岗底模式” 的反思，合理定位了政府官员、科技人员和农民三者间扮演的角色关系，验证 了贫困群众既是扶贫开发的主体也是受益者。政府作为外部推动者，通过科技扶贫项目的实施，激发贫困 群众被动 $\rightarrow$ 主动 $\rightarrow$ 群动的热情，让他们以主人翁态度置身于其中，提高其自我组织、自我脱贫、主动发展 的行为能力，将“救济式”被动扶持转变为“开发式”主动参与扶贫。同时“岗底模式”集中民智，真实 地反映贫困群众的意愿和需求，给予农民主体扶贫开发的参与权、知情权、监督权和管理权的做法，无不 渗透着国际公认的参与式扶贫理念和方法。“岗底模式” 对于深入探讨反贫困本土化与国际化的有效对接 规律，建立和完善中国特色的参与式扶贫机制具有重要借鉴意义。

从经济发展角度来讲，反贫困一般经历“自然反贫困一政府反贫困一市场反贫困”三个阶段。中国的 科技扶贫是以改变贫困群众命运和社会、经济、文化落后状态为基本目标的伟大实践。随着经济社会的发 展, 必将与国际接轨逐渐步入市场反贫困阶段。为了实现这个目标, 需要政府的支持、社会的帮助以及各 种力量的推动，但更需要贫困地区群众的广泛参与，贫困群众是这场伟大社会实践的主体。

(三)“岗底模式” 对于社会主义新农村建设的重要参考意义

全面提高农民的科技文化素质是贫困地区新农村建设的基础性工程。当前，新农村建设的制约资源， 已经由土地资源、劳动力数量、资本存量等物质资源, 逐步转向以人的知识、能力和技术水平等为主的人 力资源。而我国贫困农民的科技文化素质普遍偏低，严重制约着农业生产力的提高，影响着农民向农村二、 三产业和城镇转移的进程，是导致贫困农民增收困难的主要原因之一。人是第一位，技术和资金是为人所 用的。只要人的素质提高了, 必然会产生渴求脱贫致富的新知识、新技术的强烈愿望，就会主动寻找和应 用。行为科学理论表明: 人的行为是由动机产生的, 而动机则是由内在需要和外来刺激而引起的, 其中内 在需要是产生动机的根本条件。动机是行为的驱动力, 它驱使人们通过某种行为达到某一目标, 自觉自愿 地为实现所追求的目标而努力。因此, 只有依据不同区域特点、不同农户需求、不同生产阶段，因地制宜 地开展科技培训, 提高贫困农民的科技文化素质, 诱导和激活农民的内在潜能, 挖掘其自我脱贫、主动发 展的能力，转变其态度和行为观念，才能真正实现发展农业，富裕农民，繁荣农村的目标。

参考文献：

[1] 《中国农村扶贫开发纲要》 (2001 - 2010 年) [EB/OL]. 国务院扶贫办网 (http://www.cpad.gov.cn/)，2006-03-23.

[2] 陶佩君. 农村发展概论[M]. 北京 : 中国农业出版社，2004.08.

[3] 叶敬忠等. 农村发展研究[M]. 北京 : 中国农业大学出版社 , 2002.05.

[4] 中国科学技术协会扶贫办公室，爱德基金会. 反贫困与农村可持续发展[M]. 北京 : 中国农业出版社，2002.03.

[5] 刘桀，马天乐等. 社区林业发展与消除贫困的制度及案例研究[M]. 北京 : 中国农业科技出版社，2000.11.

(责任编辑：裴中华、李满华) 